Allen Ginsberg's genius for public life should not obscure his genius as an artist or his study of his art. -ROBERT PINSKY, 1997 U.S. POET LAUREATE

\title{
Allen Ginsberg's Genius
}

The Secret or Hermetic Tradition

In 1957, at the age of fifteen, I bought for seventy-five cents a copy of the City Lights paperback edition of Howl and Other Poems with the trademark black-and-white cover. It was the first book of poetry I ever bought, and it made me feel as cool as anyone in my high school. Howl was underground poetry, outlawed poetry. Ginsberg made it seem as though it was cool to be a teen and that teens, not adults, knew what was cool. To those of usI wasn't the only teenage beatnik in suburbia - who owned a copy, Howl conferred a strange power. Reading it brought initiation into a secret society. It bound us together and gave us a sense of identity as members of a new generation that had come of age in the wake of World War II and the atomic bomb, a generation that lived in the shadow of nuclear apocalypse. There was something wonderfully subversive about Howl, something the poet had hidden in the body of the poem because it was too dangerous to say openly, something we had to uncover and decode. 
Ginsberg didn't want to be too easily understood. As he himself would explain, Howl was meant to appeal "to the secret or hermetic tradition of art." Of course, as a teenager I didn't know there was a secret tradition of art. It was Ginsberg who introduced me to it and prompted me to pursue it.

\section{The Cold War and Literary Creativity}

Years later, I met Ginsberg in Manhattan, along with his longtime lover and fellow poet, Peter Orlovsky, and Gregory Corso, the author of Gasoline. In the I980s and I990s, I interviewed Ginsberg several times in New York and in California. In I985, after having listened to him on record albums for years, I first heard him read his poetry live. It was at College of Marin, just north of San Francisco. After the reading, we talked about the Cold War and American culture, a subject with which he had been preoccupied ever since the mid-I940s - and a subject that had more than academic interest now that Ronald Reagan was president. Indeed, he had been writing new, angry political poems, like "Birdbrain!" and "Capitol Air," that were inspired by the global crisis between East and West, communism and capitalism. "Oh, yes, the Cold War has returned with Reagan," Ginsberg said. "But it's not like the Cold War of the r940s and I95os. The CIA doesn't do the dirty work anymore, the corporations do." He complained - as he had complained many times before - about the role of the CIA in creating "a middle stratum of intellectuals and writers to be anti-Communist, to keep a lid on genuine creativity."

"Kerouac was a writer of genius," he said. "For years, he was prevented from being published by the middle-brow intellectu- 
als that the CIA had created. They had already rejected William Carlos Williams and they rejected Kerouac, too.” Perhaps no major twentieth-century American poet had a more conspiratorial frame of mind than Ginsberg did; and arguably his sense of conspiracy inspired him to write some of his best poetry, including Howl, in which scholars support wars, radios read minds, and America has turned into a fascist state. There was often more than a grain of truth in Ginsberg's conspiratorial vision. Granted, there is no evidence that the CIA was directly or indirectly responsible for Kerouac's rejections by American publishers for half a decade. But as Frances Stonor Saunders shows in The Cultural Cold War: The CIA and the World of Arts and Letters (1999), the CIA did engage in covert operations with American writers and intellectuals to win the hearts and minds of people all over the world, much as Ginsberg claimed. The CIA funded magazines such as Encounter and established organizations such as the Congress for Cultural Freedom to combat radicalism, subvert dissent, and make America seem like the only friend to freedom. The agency sent American writers and teachers to conferences to confront intellectuals and artists from the Soviet Union and the Eastern bloc countries.

Who were the CIA-sponsored intellectuals? I asked Ginsberg when we talked in Marin in I985. Lionel Trilling, Norman Podhoretz, and Mary McCarthy, he replied. In his eyes they contributed to the unhealthy climate of the Cold War as much as the cultural commissars behind the Iron Curtain did. There were few American intellectuals he did admire. At Columbia in the I940s, he insisted, Raymond Weaver - the man who discovered the manuscript of Herman Melville's masterpiece Billy Budd-was the only professor who had integrity. Ginsberg said that he and 
Kerouac, who was briefly a student there, had received their real education from men like Herbert Huncke, a hustler and drug addict they'd met in Times Square. "We got the bottom-up vision of society," he said. "We saw wealth and power from the point of view of down-and-out people on the street. That's what the Beat Generation was about-being down-and-out, and about having a sense of beatitude, too." When I asked him why he hadn't been silenced by the climate of the Cold War and the anti-communist crusaders - in fact, he had gone on writing all through the late I940s and early I950s - he said that he had never been intimidated and never felt afraid. "Kerouac and I had a zany view of the world," he said. "We had a W. C. Fields view of J. Edgar Hoover. Even in the mid-I940s we couldn't take him seriously." Indeed, in Howl there is a kind of W. C. Fields view of the FBI; J. Edgar Hoover's FBI agents are figures of absurd comedy. The poet turns the tables and talks about investigating the investigators.

"Nineteen forty-eight was the crucial postwar year," Ginsberg explained. "It was the turning point. Of course the atom bomb had already gone off in I945, and Kerouac and Burroughs and I had talked about it, but the psychological fallout from the bomb - the consciousness - didn't really hit until I948. There was the splitting of the atom, and the splitting of the old structures in society and also a sense of the inner world splitting up and coming apart." Like many other writers around the world, Ginsberg turned the atom bomb into an all-inclusive metaphor. Everywhere he looked he saw apocalypse and atomization. Everything had been blown up. And almost everywhere he looked he saw the Cold War. He was thinking of the Cold War when he wrote his 1956 poem "America," he said. "I was playing 
on the phrase 'Cold War' when I wrote, 'America when will we end the human war?"”

In the I980s, the Cold War was still very much alive for Ginsberg, both abroad and at home. He was distressed about the neoconservatism of the Reagan era, the administration's attack on radical and avant-garde artists, and the critical reception of his Collected Poems. He seemed to feel that his own work had been ignored or attacked because of the right-wing climate of the country. "Most reviewers didn't seem to actually read the book," he said. "They didn't see the growth, the maturity of my work. They were stuck in the past-with Howl and Kaddish, which they admitted are good, but they mostly argued that I was in decline." The fact that he couldn't read Howl and "America" on primetime TV infuriated him. "I still can't go on CBS or NBC and say, 'Go fuck yourself with your atom bomb,"' he complained. "America still doesn't understand. America is still trapped."

\section{Quarrel with Yourself}

In April I 986, Ginsberg spent two days at Sonoma State University. I was his host; I guided him, chauffeured him, saw to it that he was well fed and had a place to sleep. At an afternoon workshop for students, he insisted that he aimed for "candor, accurate candor, total candor" in his poetry. He never meant to "shock the bourgeoisie," he insisted. When someone asked, "What about the time you took off your clothes in public?" he said, "That was natural! That was spontaneous! Whitman didn't mean to shock and I don't either!”

Though he revised Howl, and though his revisions improved 
his poem significantly, he was unwilling to acknowledge the importance of revision in his own work. "The first thoughts are the best thoughts," he argued. "Recycled thoughts deny freshness. Register your thoughts when you have them, or when you first notice them. Cultivate the habit of noticing your mind and registering your own mind, too. Don't wait to be discovered. Discover yourself. Publish your own work and circulate your work."

Whitman influenced his work, he said, though he also acknowledged William Butler Yeats's role in shaping his poetry: "Yeats was right when he said that 'out of our quarrels with others we make rhetoric. Out of our quarrels with ourselves we make poetry." "He added, "Quarrel with yourself. Your quarrels with yourself often make the best poems. Tell yourself your own secrets, and reveal yourself. The purpose of art is to provide relief from your own paranoia and the paranoia of others. You write to relieve the pain of others, to free them from the selfdoubt generated by a society in which everyone is conniving and manipulating."

After his informal remarks, Ginsberg gave the students a series of writing exercises. Using the seminal phrase "hydrogen jukebox" as a model, he invited the young poets in the room to join seemingly unrelated words and create phrases that might offer a new, startling vision of the world. Like most good teachers, he praised the students when they read their work. "Apple-cart bloodbath," "suitcase bingo," and "windowshade midget" — to name just a few-were among his favorites.

That evening in the Commons, Ginsberg smiled, shook hands, and introduced himself to students and faculty members. All day long he had been worried about the microphones and the tape recorders - he insisted that we record him on reel-to-reel 
tapes - and just before he was to perform he requested one final sound check. The stage had been arranged like a living room. There was a coffee table, a vase filled with flowers, a pot of tea already mixed with honey, a few ceramic cups - everything placed in accord with his precise instructions. A few minutes after 8 P.M. the audience - mostly students - craned their necks, eager for the event to begin. Professor David Bromige, a Canadian-born poet who had known and admired Ginsberg for decades, took the podium and introduced him as "Sir Allen," a comment that brought a smile to Ginsberg's face.

Suddenly he was on stage, a bundle of intensely focused energy. Pumping his right foot and squeezing his little red harmonium with both hands, he began to sing "Airplane Blues," which chronicles his ongoing sexual attraction to young men-and his declining sexual powers at sixty. Like many of the poems Ginsberg read that night at Sonoma State University, "Airplane Blues" would be published, with major revisions, in White Shroud: Poems, I980-1985.

"White Shroud" - the title poem in that volume-moved the audience more than any other poem that evening. That wasn't surprising, since it describes in vivid detail a haunting dream in which Naomi Ginsberg, the poet's mother, appears alive and well in the Bronx — though she died in I957. In the r980s, he seemed to be as haunted by his mother as he'd ever been. Despite his politeness and willingness to please one and all at Sonoma, I had the feeling that he was increasingly a lonely figure - a poet who had wanted glory and now felt trapped by it.

When he died a decade later, I attended the memorial service at Temple Emanu-El in San Francisco. Rabbi Peretz-Wolf Pursan told the crowd that his own congregation had opposed a 
tribute to Ginsberg. In death he was still controversial. Andrew Shilling spoke of Ginsberg's "long karmic connection to San Francisco.” Lawrence Ferlinghetti read a poem he'd written entitled "Allen Ginsberg Dying." "I'll always remember Allen's voice," he said. "I think I'll remember his voice more than anything else." Michael McClure said he loved Ginsberg "for bringing the mercies of enlightened Buddhism to poetry." Gary Snyder said he learned from Ginsberg "the power of sharing poetry with friends and not just reading it in the privacy of one's room." Joanne Kyger said that Ginsberg had "widened the area of consciousness" and that she admired him for his "freedom of language, political honesty, and spontaneous mind." Robert Haas lauded Ginsberg for using "his fame to help his friends," and Nancy J. Peters praised him for "opening the door of poetry to so many people around the world." San Francisco clearly loved Allen Ginsberg. Elsewhere, though, his reputation seemed to be tarnished. Howl was frequently dismissed. For David Remnick, the editor of the New Yorker, Ginsberg's great poem was Kaddish, not Howl. In the New York Times Book Review, Charles McGrath depicted Ginsberg as a "cultural busybody" and an "inspired yenta." For McGrath "his most enduring contribution to our culture" wasn't Howl or Kaddish, "but the way ... he transformed the American avant-garde, and the angry alienation of the Beats, into something altogether more cheerful and benign." For me Howl has always been Allen Ginsberg's masterpiece-a horrifying, funny, surreal, and prophetic poem. So I set out to write this book about Howl. I reread all the poems, went to libraries, read the unpublished letters and manuscripts, and talked to Ginsberg's friends and acquaintances, including Ginsberg's therapist in 1955 and 1956 , when he was writing Howl. Ginsberg had ac- 
knowledged Dr. Philip Hicks's pivotal role in his development as a poet; Dr. Hicks "gave me the authority, so to speak, to be myself," Ginsberg told Jane Kramer. But Dr. Hicks himself had never talked about his patient. Now that he was retired and Ginsberg was dead, he was ready to share his memories. "Allen brought his poems to therapy and read them," Dr. Hicks said. "He brought Howl for me to read when it was still in manuscript." Ginsberg had always insisted that he never received help from anyone while writing the first draft of Howl. Dr. Hicks said that his patient worked on his poem while in therapy and that therapy helped make it possible for him to write Howl. He added, "Allen had rigid ideas of who he was supposed to be; he thought that he was supposed to be heterosexual. During one session he mentioned his homosexuality and I said something like 'So? What else is new?'" I also obtained confidential medical reports on Ginsberg from the New York State Psychiatric Institute and from Langley Porter in San Francisco, reports that reveal for the first time Ginsberg's experience as a patient and a poet inside a mental hospital, and as an outpatient in therapy.

\section{A Short History of Howl}

In a way, Ginsberg never let go of Howl. Year after year, he returned to it, continually adding to the mythology of the poem as a spontaneous work that brought him and the world out of the closet of a repressive society. In 1956 , he told the poet and critic Richard Eberhart that his intention in writing Howl was to liberate readers from their "false ... self-deprecating image" of themselves and to persuade them that they were "angels." In I965, when Tom Clark interviewed him for the Paris Review, he 
insisted that Howl, and especially the last section of the poem, was "really an homage to art." In I974, he told Allen Young, who interviewed him for Gay Sunshine, that Howl was a literal "coming out of the closet" and an "acknowledgement of the basic reality of homosexual joy." In I 975, two decades after he first sat down to write Howl, he explained - this was among his biggest literary bombshells - that it was "really about my mother." In I986, when Harper and Row published the original draft facsimile edition of Howl-modeled after T. S. Eliot's facsimile edition of The Waste Land-Ginsberg explained that his poem was meant to be an "emotional time bomb that would continue exploding ... [the] military-industrial-nationalistic complex.” For Ginsberg Howl was a magic mirror. Whenever he peered into it he saw another side, another aspect. Readers around the world, too, brought their own cultures and histories to Howl, reading it in the context of their own lives. Indeed, how we read Howl and interpret it today is in part the legacy of its legendary status from Prague to Peking, Barcelona to Budapest.

By the time that Ginsberg died in 1997 , Howl and Other Poems had sold over eight hundred thousand copies. It had been translated into at least twenty-four languages, including Spanish, Polish, Dutch, Japanese, Chinese, Hungarian, and Italian - and it was one of the best-known American poems in the world. It had played a significant part in changing poetry in America - by making it more personal, more confessional, and more akin to the performance arts. Howl also played a small part in changing the world itself by collapsing cultural boundaries at the height of the Cold War and by encouraging cultural rebellion around the worldfrom San Francisco to Havana, New York to Mexico City.

Ironically, the very fame that Howl brought to Ginsberg may 
also have caused his exclusion from the elite company of feted American poets. He received honors and grants, but the top literary prizes eluded him. Ginsberg was not shy about promoting himself or his poem; he did not honor the prescribed mold for poet behavior, which did not include tooting one's own horn. Perhaps if he had gone on writing and perfecting the formal poetry he wrote in the I940s, he might have won a Pulitzer Prize or become poet laureate. When he strayed from his original course and wrote Howl — with its wildness and exuberance - he set himself apart from the respectable crowd of poets. Many of his own Columbia classmates and teachers felt that he'd turned against them and the education he'd received at college. By writing and publishing Howl, he committed an act of cultural treason.

Adrienne Rich - the author of Diving into the Wreck (1973) and On Lies, Secrets and Silence (1979) - observed that American poetry often emerges from the "point of stress in our society." She also noted that the "stress in itself creates a search for language in which to probe and unravel what is going on here." Howl emerged from the fissures in American society after World War II, as well as from the fault lines in the author's own secret, volatile life. In his best poetry, Ginsberg dove into the wreck of himself and of the world around him to salvage himself and something worth saving of the world at large. In the act of writing Howl, he discovered the very language he needed - a language of the everyday and of Judgment Day - a language of the mundane and the apocalyptic.

"The artist is extremely lucky who is presented with the worst possible ordeal which will not actually kill him," the poet John Berryman wrote. The Pulitzer Prize-winner in poetry for 77 Dream Songs, Berryman suffered from depression before taking 
his own life in 1972 . When he wrote about suffering and death, he knew whereof he spoke. Similarly, Ginsberg came close to suicide repeatedly in the decade before he wrote Howl. He wrote about death, dying, and suicide again and again. It was deaththe death of so many members of his own generation and the spiritual death of a mechanized world - that inspired him to create his best work. Fellow poet Kenneth Koch once asked him, "What do you have to have, or to be, to start with, in order to leave yourself open to produce good poetry?" Ginsberg replied, "A little glimpse of death. And the looseness and tolerance that [it] brings." When he wrote Howl-his autobiographical/ mythological poem - he found the tolerance and the looseness he needed in order to create an American masterpiece.

\section{Do I Contradict Myself?}

In American Scream I have tried to explain what it was like for Ginsberg to write Howl-how he felt, what he was thinking, why he wrote it, and who influenced him. Ginsberg's journals, which he kept from 1937 until his death in I997, provide a clear record of his evolution as a poet and of the genesis of his poems. A storehouse of images and ideas, they are the seedbed from which many of his poems spring. Another key to understanding the man and the poet is to acknowledge the importance of his journey to San Francisco, where he began to write Howl. I have tried to show what happened to him in the Bay Area that made it possible for him to find a place in America, both as a poet and as a homosexual.

Madness is another central theme in Ginsberg's life and poetry, and I have described Ginsberg's complex and often contra- 
dictory ideas and feelings about it. Along with nakedness and secrecy, madness is at the heart of his work, and especially at the heart of Howl. And, while this book is primarily about Howl, I have also written about poems that Ginsberg wrote immediately before and immediately after Howl, including "A Strange New Cottage in Berkeley" and "Sunflower Sutra," because they help us understand both Ginsberg and Howl. Ginsberg's relationships with Kerouac and Burroughs form another primary focus in this book. Their story has been told before in books about the Beats, but no one has explored how Kerouac and Burroughs helped to shape Howl and the extent to which Howl tells their story as well as Ginsberg's. The time that Ginsberg, Kerouac, and Burroughs actually spent together was brief indeed — a few months here and a few months there. It was not, however, the exact hours that they spent together that matter most, but rather the intensity of their initial experience together in New York when the United States was at war and when they were young aspiring writerslinked by dreams and ambitions. Then and there, Ginsberg, Kerouac, and Burroughs bonded as few American writers have ever bonded before or since.

Theirs was literally a friendship hammered out in letters and in novels and poems, and across great distances. For decades they corresponded with one another, extending the dialogue about language, art, and the role of the artist that they started in New York during World War II. Howl stands as a testament to Allen's friendships and to his male friends-Jack Kerouac, William Burroughs, Neal Cassady, and Carl Solomon. It is perhaps the quintessential twentieth-century American poem to celebrate male comradeship and male bonding in the spirit of Walt Whitman and Herman Melville, and not surprisingly Kerouac and 
Burroughs recognized the genius of Howl from the moment they read the poem in typescript. That largely underappreciated story of literary friendship and literary influence is a thread that runs through American Scream.

Likewise, little attention has been paid to the influence of T. S. Eliot on Ginsberg's work. Ginsberg read Eliot, of course, and his approach to poetry was shaped by Eliot's ideas about tradition and the individual talent and about the form and the language of poetry. As Cynthia Ozick observed, "Ginsberg's 'Howl,' the single poem most representative of the break with Eliot, may owe as much, thematically, to 'The Waste Land' as it does to the bardic Whitman or to the opening of the era of anything goes. Ginsberg belongs to the generation that knew Eliot as sanctified, and, despite every irruption into indiscipline, Eliot continues in Ginsberg's ear." It was part of Ginsberg's genius as a poet that he could borrow from both Eliot and Whitman, fusing them to make something new.

Near the end of Song of Myself, Walt Whitman wrote, "Do I contradict myself? / Very well then I contradict myself, / (I am large, I contain multitudes.)" Ginsberg had a special affinity for those lines, and he frequently quoted them, especially when he wrote about Howl, his poem of immense contradictions. Howl is explosive - as befitting a poem for the atomic age — and yet it's also symmetrical. It's carefully crafted, expertly shaped. The poet and critic William Everson allowed that Howl was like a "scream from a paddy wagon," but he also noted that "even a scream has structure." Ginsberg himself suggested that the poem was a kind of scream. "I occasionally scream with exasperation (or giggles)," he wrote. "All this can hardly be called incoherence except by 
oververbal madmen who depend on longwinded defenses of their own bad prose for a livelihood."

Howl is a work of synthesis that fuses disparate elements in Ginsberg's own contradictory life: the sacred and the profane, the prophetic and the self-promoting. Howl synthesizes his early years with his parents, his college years at Columbia under the tutelage of Lionel Trilling, his hipster days in New York, and his life on the road in the I940s and I950s. Howl was also born at a particular time and place. To understand the poem, it helps to understand America and the Cold War-and the underground culture of San Francisco. "Almost all times of crisis," Octavio Paz wrote, "are fertile in great poets." Like The Waste Land, Howl was born of crisis; like The Waste Land, it is a "historical product, the fruit of a time and a place."

Sayulita, Mexico 
This page intentionally left blank 